TEME, г. XLII, бр. 4, октобар - децембар 2018, стр. 1179-1196

Оригинални научни рад

DOI: $10.22190 /$ TEME1804179S

Примљено: 18. 11. 2017.

Ревидирана верзија: 28. 2. 2018.

Одобрено за штампу: 12. 6. 2018.

UDK 316.64-057.875

. 12.6 .2018$.

\title{
ДАРОВИТИ СТУДЕНТИ \\ И ИНТЕРКУЛТУРНА КОМУНИКАЦИЈА
}

\section{Александар Стојановић ${ }^{*}$, Грозданка Гојков, Александра Гојков Рајић}

\author{
Универзитет у Београду, Учитељски факултет, Београд, Србија \\ *aleksandar.stojanovic@uf.bg.ac.rs
}

\begin{abstract}
Апстракт
У раду се приказује део резултата експлоративног истраживања које је рађено на пригодном узорку студената из шест држава региона југоисточне Европе (N973), међу којима је 182 потенцијално даровитих, односно са просечном оценом изнад 9,00, дакле, израженим академским перформансама. Посматрана је интеркултурна сензитивност даровитих студената у контексту актуелних миграционих процеса, с циљем да се анализира њихова способност прихватања плуралистичких идеја и преиспитивање супротне аргументације, јер би даровити требало да имају израженију толерантност на различитост и сл.

Применом дескриптивне методе и скалом процене као инструментом снимане су разлике у интеркултурној сензитивности даровитих у односу на друге студенте, као и разлике између студената по полу. Инструмент се односио на питање: Какве ефекте на пољу интеркултурне комуникације могу изазвати садашње миграције у Европи? Независне варијабле биле су пол и успех на студијама, а зависна ниво интеркултурне сензитивности.

Основни налаз односи се на следеће: постоје статистички значајне разлике (мале или средње) у вредновању позитивних и негативних интеркултурних ефеката у односу на пол и успех на студијама, као и да даровити у имиграционим токовима налазе више позитивних ефеката за ЕУ, а на првом месту се међу овим истиче јачање мултикултурности у ЕУ.
\end{abstract}

Кључне речи: даровити студенти, интеркултурна комуникација, миграције, алтернативни конструктивизам, плуралистичка толеранција.

\section{GIFTED STUDENTS AND INTERCULTURAL COMMUNICATIONS}

\begin{abstract}
This paper presents some of the results of an exploratory research conducted on an appropriate sample of students from six countries in the region of Southeast Europe (N-973), among them 182 potentially gifted, ie with an average grade above 9.00,
\end{abstract}


therefore with expressed academic performance. The intercultural sensitivity of the gifted students was examined in the context of the current migration processes in order to analyze their ability to accept pluralistic ideas and to reconsider the opposite argumentation, because the gifted have a greater tolerance to diversity and the like.

The differences in the intercultural sensitivity of the gifted students compared to other students, as well as the differences between students by gender, were recorded by applying the descriptive method and the scale of assessment as an instrument. The instrument was concerned with the question: what effects in the field of intercultural communication can cause current migration in Europe? Independent variables were gender and success in studies, and the dependent variable was level of intercultural sensitivity.

The main finding relates to the following: there are statistically significant differences (small or medium) in evaluating positive and negative intercultural effects in terms of sex and success in studies, and that the donation in immigration flows has more positive effects for the EU, and in the first place among these is the strengthening of multiculturalism in the EU.

Key Words: gifted students, intercultural communication, migration, alternative constructivism, pluralistic tolerance.

\section{УВОД}

По мултикултурној епистемологији, мултикултурност се у време постмодерне плуралности, и то не ретко, посматра као субјективна категорија, а вредности као релативне (Semprini, 2004: 71). У питање се доводи истина, односно релативизује се значај вредносних судова. Тако се доводе у питање схватања о универзализму, по коме постоје вредности, морални судови, избори у понашању који имају апсолутну вредност и који се могу применити на целокупно човечанство.

Прихватање плуралности животних форми, као предзнака постмодерне, времена у коме смо, намеће питање домета и ограничења плуралности са ознакама екстремне тенденције релативизације и личним схватањима и осмишљавањима циљева личном прагматичном перспективом, без узимања у обзир универзалних начела. У време постмодерне и конструктивизма не изгледа немогуће гледиште да се схватање појма мултикултурност обликује према личним намерама и мерама, дакле, без одређене суштине. Стога покушаје одређивања појма мултикултурност отежава његова неухватљивост, субјективност, која се сматра његовом инхерентном карактеристиком (Stojanović, 2012). Постмодерно стање у основи је контроверзног односа између плурализма животних форми и њихове неминовне међузависности. Зато је интеркултурализам данас већ увелико саставни део основних принципа, не само данашње Европе него и света, схваћен као услов мира, стабилности и просперитета. У основи истог је неговање свести о људским разликама, разликама култура и животних стилова и ставова о културама отвореним за 
промене и прилагођавања. Концепт интеркултурализма већ се дуже време подржава због хуманистичке оријентације, истицања значаја способности за емпатију и због све реалније ситуације мешања култура у глобалном свету. У европском интеркултурном простору тежи се интеркултурном дијалогу, посвећености заједничким вредностима, поспешивању разумевања, толеранције, избегавање негативних страна културног плурализма.

Међутим, поменути принципи и процеси уздрмани су великим имиграционим токовима који већ дуже време преплављују Европу, праћени бауком тероризма, који је свеприсутан. С разлогом се поставља питање колико ће унутрашње мере борбе против тероризма утицати на позитивне токове интеркултурне сензитивности које су последњих деценија биле предзнак ЕУ. Изазови глобалног тероризма иду ка формирању коалиције великих сила за обуздавање исламског радикалног фундаментализма, у тренутку који има обележја новог времена. Дестабилизовањем региона Блиског истока, радикални џихадисти, користећи настали хаос у региону и шире, успели су да створе јак политички ентитет - тзв. Исламску државу, отворену глобалну претњу, не мирећи се са интересима светских сила и супротним системима вредности истих.

Иза скице тренутне стварности ЕУ, обележене несигурношћу, неефикасношћу система државне безбедности у одбрани цивилног становништва, јављају се и обриси новог менталитета за који се сматра да има карактеристике напуштања друштва дисциплине и уласка у друштво шпијунирања (Greber, 2015: 33-36). Остаје питање како ће се све ово одразити на мигранте који су до сада већ у стотинама хиљада, тј. близу милиона, ушле у ЕУ и који у истом, или и већем броју, рачунају на ЕУ као своје уточиште, безбедносно, економско и сл. Како ће ово изгледати, односно колико је оствариво, засад је неизвесно.

Према некима (Rubini, 2015: 37), ЕУ ће се дестабилизовати ако се не нађе економско решење за постојећу имиграциону кризу. Хоће ли бити солидарности, поделе ризика и видљивије институционалне интеграције имиграната и синхронизације помоћи у обнови држава из којих долазе имигранти и услова за економски опоравак истих, или ће се доћи у ћорсокак глобалног хаоса, или још горе, почетка Трећег светског рата? Све су ово дилеме и питања на која ЕУ, па ни остатак света, данас немају одговора.

У наведеном контексту, интересовало нас је како једно од питања која су испреплетана у комплексним процесима у ЕУ, а делом и западног света, виде даровити студенти једног дела југоисточне Европе, земаља које су у ЕУ или ван ње. То питање односи се на интеркултурну комуникацију и сензитивност коју даровити имају у постојећим имиграционим токовима. 


\section{ТЕОРИЈСКИ ОКВИР ИНТЕРКУЛТУРНЕ КОМУНИКАЦИЈЕ}

За теоријски оквир интеркултурности из угла модерне, као и наслова којим се овај рад бави, значајно је поменути Хабермасово (Habermas, 1988) посматрање феномена радикалне плуралности, коју перципира као претњу хуманизму. Он сматра да усредсређивање постмодерне на плуралност у нормативном смислу подразумева способност личности за толеранцију, која у основи треба да има свест о могућности недостатка аргументације. Зато се захтева промишљени однос према плурализму и толеранцији, који данас у имиграционим токовима, мешању нација нажалост све чешће изостаје (Zimmerman, 2008). Како су даровити по својим когнитивним, а често и моралним перформансама, за корак испред других, очекује се да су више од других способни да схвате да у постмодерни знање нема универзалне критеријуме којима би се могло доћи до консензуса, те да се морају тражити други начини да би се до истога дошло, тј. да се договор може постићи и по принципима постмодерне, у ситуацијама када учесници нису сагласни у суштинским питањима. Консензус се посматра као циљ до кога се може доћи рационалном аргументацијом, те се из угла даровитих посебност, сингуларост и хетерогеност не морају сматрати претњом за споразумевање чак ни у случајевима када су обе стране сасвим супротних стајалишта.

За разлику од пројекта модерне (Habermas, 1988), у коме се радикални плурализам сагледавао као претња идејама хуманизма, солидарности или еманципације, постмодерна се усредсређује на хетерогеност модерног плурализма - не на рационалну аргументацију, него на дискурзивно окружење и компетенције учесника. Даровити би, према теоријским становиштима, с обзиром на своје способности, могли да схвате да плуралистичка толеранција не значи да је све у реду и да све треба да се прихвати (Giegel, 1992, prema: Gojkov, 2005). Њихов когнитивни систем може да издржи толеранцију на разлике, што је тесно везано за свесност о недовољности информација, односно аргумената за закључивање. Усредсређивање на комплексност, дисконтинуитет и разлике, даровите, пре других појединаца, води ка постмодерној скромности (Kelly, 1955), насупрот веровању да постоје рационална решења за сваки проблем и да постоји виши смисао у свакој разлици (Gojkov, 2006: 78). Претходно води ка алтернативном конструктивизму као могућем теоријском полазишту за посматрање интеркултурне сензитивности и комуникације, односно Келијеве теорије личних конструката као основи аргументације оквира за проблем овога истраживања, који се односи на питање мере уплитања плурализма култура Европе у националне културе, а тиме и интеркултурну осетљивост. У оквиру овога посматра се питање начина којима педагогија трага за потпунијим самоопажањем и саморефлексивним самовођењем ка самопроменама којима би се 
осигурала слобода деловања личности по узору на савремене филозофске дискусије које воде ка стварању европског идентитета (Gojkov, 2006). У претходно спада и схватање да питање интеркултурне сензитивности подразумева особу која је способна да развија позитивне емоције разумевањем и прихватањем културних разлика (Chen i Starosta, 1996, 2004) и стварати ефикасна понашања у интеркултурној комуникацији. Адлер (Adler, 2001) истиче следеће карактеристике интеркултурне сензитивности појединаца: културна осетљивост, отвореност, разумевање, критичко и потпуно размишљање, флексибилност у размишљању и деловању, које заједно омогућавају интеркултурну комуникацију између особа различитих култура.

Посматрано из угла даровитих и њихових когнитивних карактеристика, поједина истраживања (Đurišsić-Bojanović, 2009) иду у прилог закључку да даровити поседују јаче изражене црте комплексног интегративног когнитивног стила, што даље води закључку да особе са јаче израженим димензијама апстрактног мишљења могу боље да прихвате плуралност идеја. Из угла персоналних карактеристика личности, у овоме су успешнији даровити, који иначе имају израженији комплексни интегративни когнитивни стил (Gojkov, 1995). То говори о значају особина личности, односно указује на то да се препреке за прихватање плуралности могу тражити у особинама личности, које су иначе у тесној вези са когнитивним стилом.

Бољем разумевању налаза истраживања које се даље представља могу послужити и ставови теорије интегративне комплексности (Đurišić-Bojanović, 2009), у којoj се објашњења за разумевање природе когнитивних процеса на којима се заснива плуралност налазе у интегрисању когнитивних процеса у мање или веће аутономне целине, што омогућује мању или већу отвореност за плуралност. Налази истраживања упућују на хипотетичку констатацију да је интекултурна сензитивност везана за когнитивну плуралност, те ће се овим истраживањем проверавати претходна теоријска становишта, као и поједини елементи Келијеве психологије личних конструката, по којој се понашање личности, а тиме и интеркултурна сензитивност, боље схвата ако се посматра у ширим временским димензијама. Тада се однос мултикултурног и националног може посматрати као два пола културе, како их види Аврамовић (2003: 98). Он сматра да су се питања односа ова два пола увек постављала, различито тумачила, али су се увек на неки начин прожимала. То значи и да ће то увек бити и ствар избора државне културне политике, појединаца и стваралачких група. Ово је значајно за образовање као фактор мултикултурне комуникације појединца, те његов однос према култури свога народа, као и културним вредностима других, односно за прихватање плуралности у интеркултурним комуникацијама Европе данас, па и шире. 
Данашње прилике у Европи из угла мултикултурности и жеља ка остваривању консензуса међу државама унутар ње по питању имиграционе политике, а уз то и елемената образовне политике која би била усмерена ка култури толеранције и интеркултурне сензитивности, подразумевају и боље разумевање савремености и непрестаних промена на глобалној светској сцени. Иначе, промене као саставни део живота и тежње да се у јединственом образовном простору људи приближи једне другима подразумевају да се њихов микро и макро космос учине што функционалнијим и сигурнијим. У тим сталним дешавањима у свету, образовање у јединственом образовном европском простору могло би функционисати као интегрална целина, чији делови имају своје узајамне односе, који не морају бити идентични. Из теоријског угла, као решење за претходно, нуди се Келијево схватање приближавања, које се односи на лични угао: „...живот је, онда, у нашем начину размишљања, окарактерисан својом суштинском мерљивошћу у временској димензији и својом могућношћу да представља алтернативне облике стварности, задржавајући притом свој сопствени вид стварности" (Kelly, 1955: 67). Дакле, посматрано из угла савремене психологије личних конструката и алтернативног конструктивизма, личности се дозвољава да и феномен интеркултурне осетљивости, као један од аспеката интеркултурности, посматра са једног или другог краја континуума (мултикултурно-национално). Ово из угла постмодерних схватања оставља отвореним питање могућности да се сва опажања узимају као релативна, те могућности да се у сваком тренутку преиспитују и мењају у складу са способношћу за имагинацијом и интегрисаношћу когнитивне структуре личности (Kelly, 1955). Ово нуђење релативизма и претендовање на нестандардно мишљење не мора да сужава поља интелектуалне аутономије у процесу учења. Дакле, и мултиперспективизам - толеранција сапостојања и истовремено неговање различитих перспектива, дух толеранције, дисхармонија и њихово дуготрајно дијалошко усклађивање - може да буде пут ка спречавању хегемонизације и доминације. Наравно, подразумевано је прихватање стварности помоћу конструката, ослоњених на сопствени референтни оквир, те прихватање Келијевог става о немогућности сазнавања ван граница искуства личности. Једноставније речено, наш систем конструката заснива се на нашем референтном оквиру, што је из угла теме овога рада значајно, јер упућује на значај образовања за интеркултурну сензитивност. Могли бисмо, у складу с овим, посматрати тежње за интеркултуралношћу као плуралистички садржајни, односно образовни контекст.

Налази овог истраживања су у извесној мери тест за аргументацију способности прихватања плуралистичких идеја и преиспитивање супротне аргументације код даровитих, јер се претпоставља да 
су они отворени за нове идеје, да имају изражену толерантност на различитост и сл. Дискусије још трају око питања: Зашто су неке особе отворене за нове идеје, а друге не? и Да ли је у питању разлика у когнитивном функционисању или су неке друге психолошке варијабле дистинктне?

Поборници когнитивно-развојног становишта (Colings, 1994; према: Đurišić-Bojanović, 2009: 97) сматрају да постоји могућност да се плуралност идеја прихвати као начин мишљења појединца. Ово се објашњава ставом да плуралност идеја подразумева конвергентне и дивергентне димензије мишљења. Сматра се да преиспитивање супротних аргумената укључује оба когнитивна стила (ибидем). Нека ранија истраживања (Gojkov, 1995: 234) указују на потребу да се код студената развија плуралистички когнитивни стил. Нађено је значајно слагање одређених димензија когнитивног стила и дидактичких инструкција, што указује на њихову кореспонденцију, чиме се подиже ефикасност и креативност у проблемским ситуацијама. Међутим, ово није довољно да се закључи да је могуће развијати плуралистички когнитивни стил, иако је у налазима других истраживања ово процењено као могуће. Питање које свакако остаје отворено је: Колики су домети дидактике у развоју особина когнитивног функционисања? Чини се да теорија интегративне комплексности (ĐurišićBojanović, 2009) доприноси разумевању природе когнитивних процеса који се интегришу у мање или више аутономне процесе, отворене за плуралност. Међутим, и поред покушаја да фокусира дидактичке поступке који погодују формирању плуралности когнитивног стила, ни она није успела у потпуности да сагледа механизме којима се аутономија у когнитивном функционисању формира.

Налази ранијих истраживања (Stojanović i Gojkov, 2009: 56) у студентској популацији Србије ${ }^{1}$ говоре у прилог томе да испитани студенти имају добру интеркултурну осетљивост. Такође је констатовано да варијабла пол није значајан предиктор за интеркултурну осетљивост. Међутим, потврђен је значај образовања за интеркултурне комуникације кроз успех на студијама, који је изражен као значајан предиктор интеркултурне осетљивости. Уочљива је и по-

\footnotetext{
${ }^{1}$ Истраживање је експлоративног типа. Вршено је скалом ставова Ликертовог типа: ICSSQ - скала интеркултурне осетљивости. Скала је са малим изменама преузета од Кристине Холм, Петрија Нокелајнена и Кирси Тири (Kristina Holm, Petri Nokelainen i Kirsi Tirri, 2009), који су испитивали интеркултурну осетљивост ученика̂ основних школа старости од 12 до 16 година у Финској. Скалу су поменути аутори засновали на Бенетовом (Benett, 1993) развојном моделу интеркултурне осетљивости (DMIS), који представља концептуалну алатку за постављање одређених реакција ка културним разликама. DMIS у себи садржи две групе стадијума (три етноцентричне и исто толико етноузајамне интеркултурне осетљивости).
} 
тврда тезе да је интеркултурна осетљивост узрокована у значајној мери срединским факторима (место студирања је значајна варијабла за интеркултурну осетљивост). Налази других истраживања биће наведени уз даљи приказ и интерпретацију налаза овог истраживања.

\section{МЕТОДОЛОШКИ ОКВИР ИСТРАЖИВАЬА}

У раду се посматра део налаза једног ширег експлоративног истраживања којим је тестирана теза о интеркултурној сензитивности даровитих студената у делу југоисточне Европе у контексту актуелних миграција.

Циљ истраживања био је да се сагледа какве ефекте на пољу интеркултурне комуникације изазивају садашње миграције у Европи. Истраживање је усредсређено на питања како даровити студенти доживљавају талас миграција из угла интеркултурне комуникације, из позитивног и негативног угла, односно како виде његове позитивне ефекте, а како негативне.

Постављена је хипотеза да ће даровити студенти бити статистички интеркултурно сензитивнији од осталих испитаних студената, те да ће видети позитивне и негативне ефекте актуелног миграционог таласа, као и да ће рационални елементи интеркултурне размене ићи у правцу хуманих и културно вредних, оплемењујућих елемената размене. Тиме би се потврдила теза о потпунијем самоопажању даровитих и саморефлексивним, самовођеним променама, које су у основи деловања личности о којима говоре савремене филозофске дискусије, које иду у прилог стварању европског идентитета са предзнаком хуманости, слободе и толеранције.

Радне хипотезе биле су:

- Даровити имају статистички значајно јачу интеркултурну осетљивост од осталих испитаних студената, што се огледа у већој удубљености у могућности интеркултурне размене између миграната и аутохтоних етничких група у ЕУ, као и у томе што су јаче наглашене позитивне могућности, односно последице од негативних;

- Пол на студијама је значајан предиктор за интеркултурну осетљивост.

Истраживање је вршено скалом процене, којом је сагледавано какве ефекте могу изазвати садашње миграције на културном пољу Европе. Испитаницима је понуђено да одаберу пет најзначајнијих ефеката који по њиховом мишљењу могу бити позитивни и да их рангирају, а затим да одаберу 5 ефеката који по њиховом мишљењу могу бити негативни и да их рангирају ( 1 је најмања, а 5 највећа вредност). 
Провера метријских карактеристика инструмента показала је следеће: поузданост типа унутрашње конзистентности скале интеркултурне осетљивости утврђена је Кронбаховом методом. За скалу у целини Кронбахов алфа коефицијент износи 0,68, што указује на то да је унутрашња конзистентност скале средње величине, тј. да ајтеми скале у средњем степену мере исти конструкт. Конструкт валидност скале интеркултурне осетљивости испитан је експлораторном факторском анализом ајтема скале. Факторска анализа је извршена методом главних оса, са варимакс ротацијом и Кајзеровим критеријумом за одређивање броја фактора. Утврђено је да скала мери осам фактора који објашњавају 62 \% укупне варијансе ајтема скале интеркултурне осетљивости. Представљене метријске карактеристике дозвољавају да се закључи да је ова скала примењива на узорку студената које смо имали намеру да испитамо.

Испитивање је извршено на узорку од 973 студента из Румуније, Македоније, Хрватске, Словеније, Босне и Херцеговине и Србије, од којих је 182 било са високим просеком изнад 9,00, који су узети као академски (потенцијално) даровити, јер су се већ остварили на пољу академских постигнућа. Узорак је био хотимичан. Испитаника женског пола било је 76\%, а испитаника мушког пола $24 \%$. Студенти су испунили штампану верзију скале процене за време једног часа крајем 2016. године. Требало је да процене свој став према изјавама које мере оријентације интеркултурне осетљивости.

Као независне варијабле у овом истраживању посматране су пол и успех на студијама, а као зависна узета је интеркултурна осетљивост. У истраживању је коришћена метода неексперименталног систематског посматрања.

\section{НАЛАЗИ И ИНТЕРПРЕТАЦИЈА}

Даровитост и интеркултурна осељивост

Посматрањем утицаја варијабле даровитости на интеркултурну осетљивост, запажа се да испитаници са просечном оценом изнад 9 чешће наводе само позитивне или само негативне ефекте и тврде да постоје само позитивни или само негативни ефекти, док испитаници са просечном оценом испод 9 набрајају и једне и друге ефекте чешће. Спровођењем $\chi^{2}$ теста, констатована је повезаност на нивоу $0,05\left(\chi^{2}=23,176 ; p=0,4\right)$ између варијабле ,даровитост” и варијабле „први позитивни избор”. Утврђен је мали утицај $(\mathrm{V}=0,26)$ и коефицијентом Пирсонове линеарне корелације утврђена је ниска, али значајна позитивна корелација $(r=0,10$; на нивоу значајности 0,05$)$ између даровитости и констатација о позитивним ефектима имиграционих токова у ЕУ. Дакле, испитаници са просечном оценом изнад 9 чешће него испитаници са просечном оценом испод 9 констатују 
већу израженост позитивних ефеката миграција него негативних. Такође, Пирсонова линеарна ниска негативна корелација $(\mathrm{r}=-0,18)$ на нивоу значајности 0,05 између даровитости и негативних ефеката миграције је потврда претходне процене даровитих о већим позитивним утицајима.

Тумачење овог налаза могло би ићи у правцу јаче интеркултурне сензитивности даровитих, који у повећавању различитог састава становништва европских земаља виде, више од других, плурализам као главно обележје овог простора, као уосталом и времена у коме живимо, тј. савремености света уопште. Овај се налаз може тумачити из угла постмодерног трагања ка начинима да се у хетерогености као суштинској особености плуралности дође до јединства у социјалној димензији, која је и у теоријском погледу још увек спорна. Ово је питање постмодерног погледа на социјални контекст савремености и као такво присутно већ и пре имиграционе кризе у ЕУ. Испитани даровити овим налазом наговештавају могућност да се размишља у правцу потврда - јединства и трајања као главних одлика модерног (метафизичког) сна. То би могло поткрепити тврдњу да се постмодернизам манифестује као плуралност, коју испитани студенти не виде као опасност другим идејама за које се савремени филозофски правци залажу, а који се, пре свега, односе на хуманизам и еманципацију (Usher и Edwards, 1999; према: Gojkov, 2008). Овај налаз опонира тврдњи да постмодернизам критикује „веру у рационалност и науку са њеним обећањем и веру у сигуран напредак у сврху побољшања човека" (Foster i Herzog, 1994; према: Gojkov, 2005).

\section{Утищај способности на први ,позитиван избор” испитаника са просечном оченом изнад и испод 9}

У графичком приказу 1 види се да се испитани са просеком изнад 9 опредељују за мултукултурност, размену знања и добробит за мигранте као позитивне аспекте интеркултурних размена у миграционим токовима.

Претходни налази су, у извесној мери, тест за аргументацију способности прихватања плуралистичких идеја и преиспитивање супротне аргументације код даровитих. Очекивано је, што овај налаз потврђује, да су они отворени за нове идеје, да имају изражену толерантност на различитост и сл., како је и у теоријским основама за заснивање ове хипотезе поменуто. Могло би се, такође, закључити да су ови налази сагласни са налазима других истраживања, која, такође, закључују о постојању блиског односа црта личности и когнитивних реакција, што је у теоријском осврту схваћено као суштина сложености когнитивног стила и што упућује на могућност да индивидуе са јаче израженим димензијама апстрактног мишљења могу боље да прихвате плуралност идеја. Теорија интегративне ком- 
плексности (Đurišić-Bojanović, 2009) изгледа да на први поглед даје објашњење за доприносе разумевању природе когнитивних процеса који се интегришу у мање или више аутономне, бар када су даровити у питању, укључујући и отвореност за плуралност.

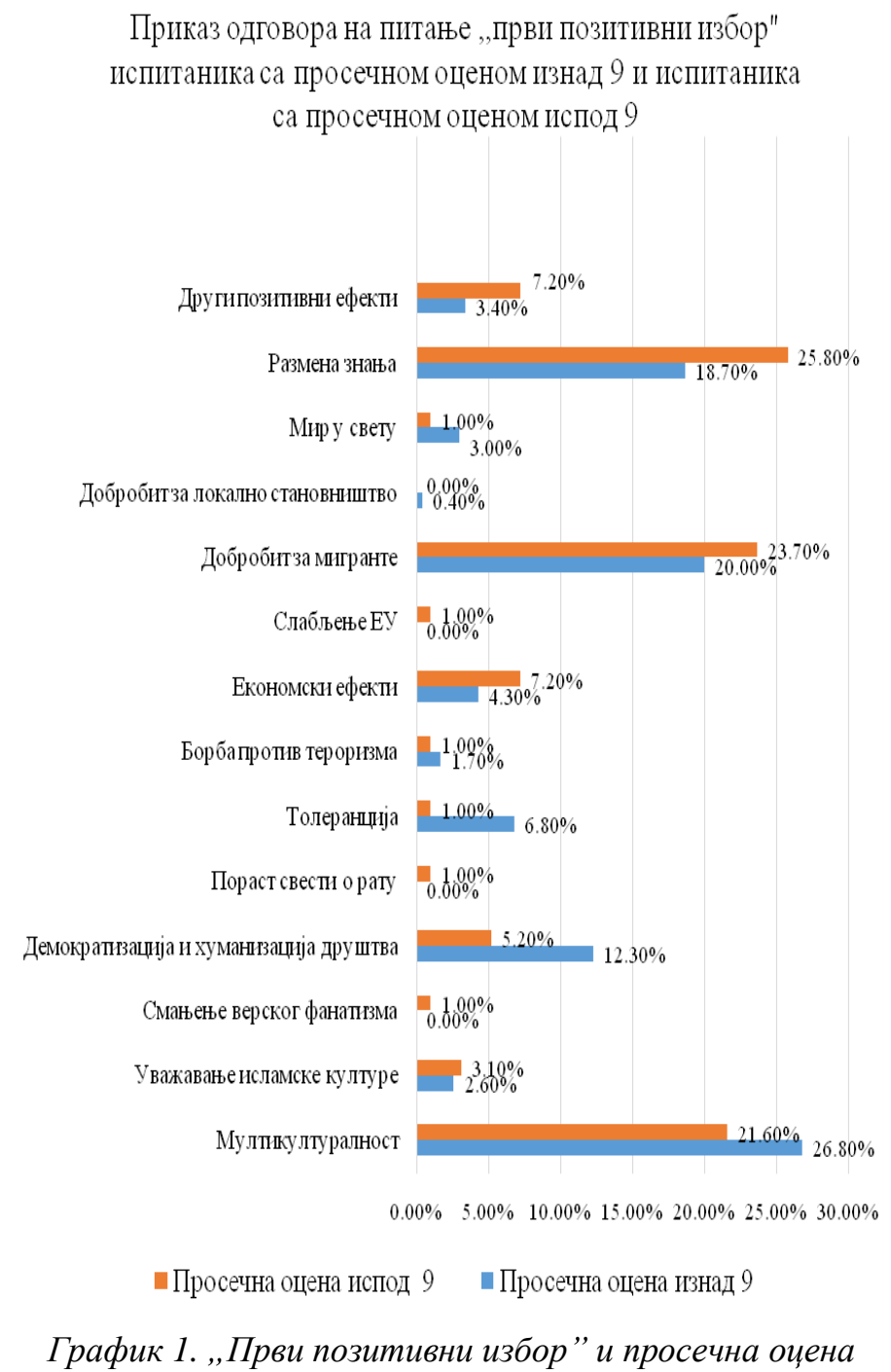

Претходни налази упућују на закључак да су теоријске поставке делимично подупрте налазима истраживања, те да је интеркултурна сензитивност везана за плуралност, а плуралност је, такође, сложена, јер зависи од сложених когнитивних процеса, који у себе, попут когнитивног стила, укључују не само когницију него и шире 
структуре, конструкте. Испреплетаност ових елемената свакако је у основи интеркултурне комуникације и сензитивности. Показало се да даровити студенти, као посебна групација младих, реагују сензитивније у позитивном смислу, тј. да, према претходним теоријским становиштима, могу да прихватају плуралност, да буду јаче сензитивни на позитивне интеркултурне утицаје тренутних имиграционих токова, што би значило потврду суштине претходно имплицираних теоријских становишта.

\section{Утицај пола на први ,позитиван избор” испитаника}

Друга хипотеза односила се на значај пола као предиктора за интеркултурну осетљивост. Хи квадрат тестом независности констатована је статистички значајна веза $\left(\chi^{2}=22.280, \mathrm{p}=0,05\right)$ између варијабли „пол” и „први позитивни избор”. Дакле, претпостављало се да ће студенти у односу на пол различито реаговати на питања о ефектима интеркултурне размене имиграционих токова у ЕУ.

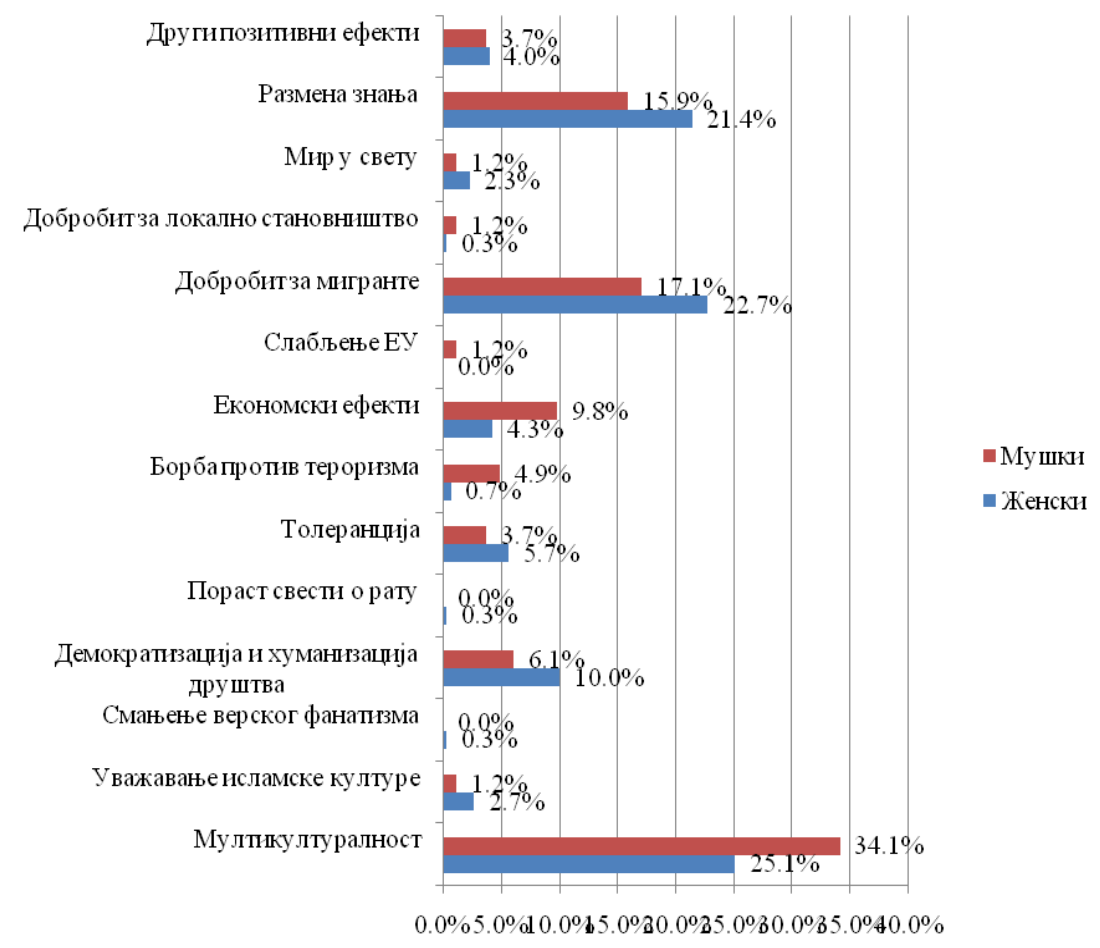

График 2. Пол и први избор позитивних ефеката интеркултурне размене имиграчионих токова у ЕУ 
Тако је налазима потврђена ова хипотеза. Утврђен је мали утицај $(\mathrm{V}=0,24)$. Разлика је из угла позитивних аспеката испољена у корист женских испитаника у погледу размене знања и добробити за мигранте, а у корист мушкараца у погледу мултикултурности. Мултикултурност је иначе најјаче испољен позитиван ефекат интеркултурних размена тренутних миграционих токова у ЕУ.

Утицај способности на први ,негативан избор” испитаника са просечном оченом изнад и испод 9

Приказ одговора на питање „први негативни избор" испитаника са просечном оценом изнад 9 и испитаника са просечном оценом испод 9

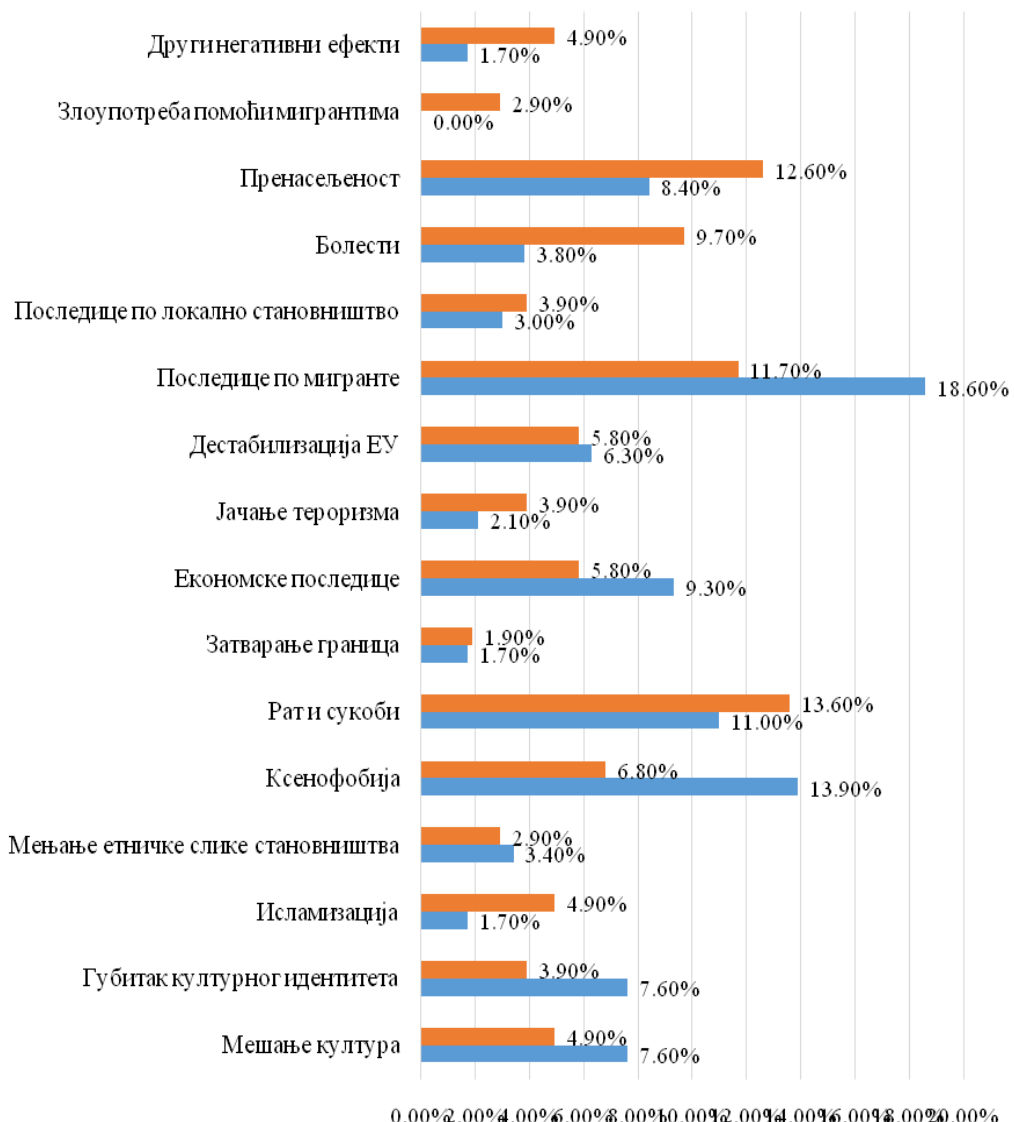

п Просечна оцена испод 9 - Просечна оцена изнад 9

График 3. „Први негативни избор” са просечном оценом изнад и испод 9 
Налази у Графику 3 аргументација су претходних констатациja, јер даровити као негативне ефекте издвајају последице по мигранте и ксенофобију, што заједно са претходним представља потврду хипотезе да даровити имају статистички значајно јачу интеркултурну осетљивост од осталих испитаних студената. Ово се, како се види, огледа у већој удубљености у могућности интеркултурне размене између миграната и аутохтоних етничких група у ЕУ, као и у томе што су јаче наглашене позитивне могућности, односно последице од негативних.

\section{Утицај пола на први ,негативан избор” испитаника}

Хи квадрат тест независности упућује на констатацију о постојању статистички значајне повезаности између посматраних варијабли $\left(\chi^{2}=57.147, \mathrm{p}=0,000\right)$, тј. између варијабли „пол” и ,први негативни избор”. Утврђен је средњи утицај $(\mathrm{V}=0,38)$.

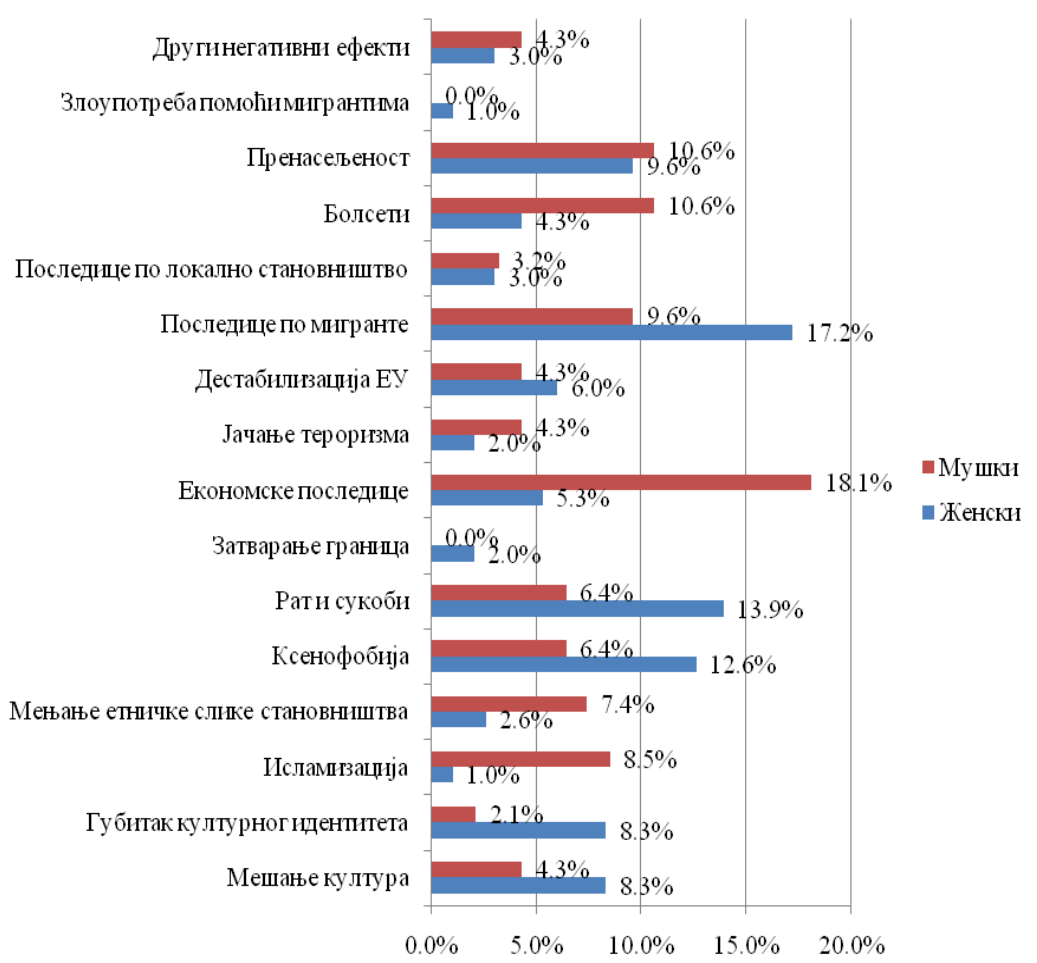

График 4. Пол и први избор негативних ефеката интеркултурне размене имиграчионих токова у ЕУ 
Подаци у Графичком приказу 4 указују на то да мушкарци негативне аспекте виде у економским ефектима, болестима и пренасељености ЕУ, а женски испитаници у последицама по мигранте, сукобима и јачању ксенофобије.

\section{ЗАКљУЧАК}

Основни налаз одваја даровите студенте од осталих и односи се на следеће: даровити студенти сматрају да процеси мешања култура не могу и не треба да се заустављају, јер се различити видови приближавања на овај или онај начин временом одвијају, посебно данас, када је свет умрежен и глобализован. Зато се, у складу са Келијевим погледом на личност, кога обележава алтернативни конструктивизам, дозвољава прихватање различитости, тј. плуралности у смислу да се питање (интеркултурно-национално) посматра са различитих становишта. У теоријском смислу, подразумевано је поштовање релативности опажања појединца, као и неопходност да се иста у поновљеним проверама, са новим аргументима могу мењати, тј. реконструисати. Даровити студенти су испољили, онако како време постмодерне подразумева, толерисање различитости. Резултати показују да они схватају да овакав однос не значи апсолутно прихватање, односно слагање, него да се прихватањем различитости у мишљењима може доћи до неког консензуса који не мора бити обострана сагласност, али значи разумевање и прихватање различитости ставова и разумевање значења тих разлика. У контексту истраживања интеркултурне комуникације и сензитивности, ово може да се тумачи тако да је данас значајно прихватити чињенице са више разумевања за постојање различитости и тежити толерантном прихватању истог од другог члана дискурса. Ово би из васпитно-образовног угла могло ићи у правцу посвећивања пажње стицању компетенција за прихватање противуречности, што би се могло сматрати значајнијим од развијања компетенција за консензусно рационалну аргументацију.

У овом истраживању су се даровити определили за позитивну страну, мултикултурност имиграционих токова у ЕУ, мултикултурну комуникацију појединца, у којој исти може зрело да се одреди како према свом културном идентитету тако и према идентитету других, чиме се ствара простор за прихватање плуралности у интеркултурним разменама имиграција у Европи данас.

Налази иду у прилог Келијевом схватању да даровити сами конструишу схватања културних идентитета сопственог, као и других народа, супротстављајући их реализму, тј. оном облику реализма којим се ствари редукују на неке од својих аспеката. Ово је у складу са схватањем да разумевање култура, као ни интеркултурна сензи- 
тивност, нису независни од когнитивног функционисања, односно имагинативних капацитета људског ума. У постмодерним схватањима све се релативизује, па и сазнања о сопственој култури и културама других народа, а тиме и интеркултурна сензитивност, јер је све подложно замени и ревизији.

Прихватање плуралитета, као одлика когнитивних структура даровитих, као основа за тумачење налаза, везује се и за налазе истраживања (Sternberg, Grigorenko i Zengova, према: Đurišić-Bojanović, 2009) којима се тврди да је холистички и комплексни когнитивни стил у тесној вези са имагинативним, флексибилним начинима гледања на стварност, док је конвергентни облик мишљења везан за једноставније, научене, конкретне приступе. Истраживања комплексног интегративног когнитивног стила указују на то да особе са јаче израженим димензијама апстрактног мишљења могу боље да прихвате плуралност идеја. Из угла персоналних карактеристика личности са комплексним интегративним стилом, то би одговарало даровитима и могло би се узети као још један корак ка разумевању налаза овог истраживања. Запажање да се препреке за прихватање плуралитета идеја могу тражити и у особинама личности отвара ново поглавље ове проблематике и упућује на даље, дубље бављење овим питањима.

\section{ЛИТЕРАТУРА}

Adler, N. (2001). International dimensions of organizational behaviour. $4^{\text {th }}$ ed. Boston: PWS-Kent.

Avramović, Z. (2003). Čiji je književnik i njegovo delo [To whom do the Writers and their Work Belong]. Sremski Karlovci i Novi Sad: Izdavačka knjižarnica Z. Stojanovića.

Bennett, M.J. (1993). Towards ethnorelativism: A developmental model of intercultural sensitivity. In R.M. Paige (Ed.), Education for the intercultural experience (pp. 21-71). Yarmouth, ME: Intercultural press.

Chen, G.M., i Starosta, W.J. (1996). Intercultural communication competence: A synthesis. Communication Yearbook, 19, str. 353-384.

Chen, G.M. i Starosta, W.J. (2004). Communication among cultural diversities: A Dialogue. International and Intercultural Communication Annual, 27, str. 3-16.

Đurišić-Bojanović, M. (2009). Multikulturalnost i multiperspektivnost u obrazovanju [Multiculturalism and Multiperspectivity in Education]. U: J. Šefer, S. Joksimović i S. Maksić (prir.), Uvažavanje različitosti i obrazovanje [Respect for Diversity and Education]. Beograd: Institut za pedagoška istraživanja.

Gojkov, G. (1995). Kognitivni stil u didaktici [Cognitive Style in Didactics]. Vršac: VŠV.

Gojkov, G. (2005). Didaktika i postmoderna [Didactics and Postmodernism]. Vršac: VŠV.

Gojkov, G. (2006). Metateorijske koncepcije pedagoške metodologije [Metatheoretic Conceptions of Pedagogical Methodology]. Vršac: VŠV.

Gojkov, G. (2008). Metodološki problemi istraživanja darovitosti [Methodological Problems in Giftedness Research]. Vršac, VŠV.

Greber, D. (2015). Zidovi su izgovor, nisu rešenje [Walls are an excuse, not a solution]. Beograd: NIN, 34. 
Habermas, J. (1988). Filozofski diskurs moderne [Philosophical Discourse of Modernism]. Zagreb: Globus.

Holm, K., Nokelainen, P. \& Tirri, K. (2009). Intercultural and religious sensitivity of Finish lutheran 7th-9th grade students. In G. Skeie (Ed.), Religious education and diversity - Nordic perspectives (pp.131-144). Munster: Waxmann.

Kelly, G.A. (1955). The Psychology of Personal Constructs. New York: Norton.

Rubini, N. (2015). Novi Maršalov plan ili treći svetski rat [New Marshall Plan or Third World War]. Beograd: NIN, 32.

Semprini, A. (2004). Multikulturalizam [Multiculturalism]. Beograd: Clio.

Stojanović, A. \& Gojkov, G. (2009). Nacionalni identitet i susreti kultura iz ugla darovitih [National identity and cultural encounter from the angle of the gifted]. U: Zbornik Filozofskog fakulteta u Novom Sadu. Novi Sad: Filozofski fakultet.

Stojanović, A. (2012). Uloga škole u negovanju različitosti kultura i moralnih vrednosti u vreme postmoderne [The Role of the School in Cultivating the Diversity of Cultures and Moral Values During the Postmodern Period]. U: N. Hrvatic \& A. Klapan (Eds.), Pedagogija $i$ kultura: Teorijsko-metodološka određenja pedagogijske znanosti [Pedagogy and Culture: Theoretical and Methodological Determinants of Pedagogical Science], pp.372-380. Zagreb: Hrvatsko pedagogijsko društvo.

Zimmerman, B. J. (2008). Goal setting: A key proactive source of academic selfregulation. In D. H. Schunk \& B. J. Zimmerman (Eds.), Motivation and selfregulated learning: Theory, research and applications (pp. 267-295). Mahwah, NJ: Erlbaum.

\title{
GIFTED STUDENTS AND INTERCULTURAL COMMUNICATIONS
}

\author{
Aleksandar Stojanović, Grozdanka Gojkov, Aleksandra Gojkov Rajić \\ University of Belgrade, Teacher Education Faculty, Belgrade, Serbia
}

\section{Summary}

Interculturalism, as one of the leading principles of the modern world, promotes an endeavor to achieve the imperatives of peace, stability and prosperity by relying on fostering common culture and intercultural co-operation. The concept of interculturalism has been supported for a long time due to humanitarian orientation, and the growing intensification of cultures in the global world. Given that Europe has been flooding large immigration flows for a long time, we were interested in how gifted students of one part of South East Europe are experiencing these processes.

The aim of the research was to examine the effects of intercultural communication on current migration in Europe. The research focuses on how gifted students experience a wave of migration from the angle of intercultural communication, from a positive and a negative angle, or how they see its positive effects, and how negative. It is hypothesized that donated students will be statistically intercultural more sensitive than other students studied, and will see the positive and negative effects of the current migration wave, and that the rational elements of intercultural exchange will go towards the human and culturally valuable, refining elements of the exchange.

The study was carried out on a voluntary sample of 973 students from Romania, Macedonia, Croatia, Slovenia, Bosnia and Herzegovina and Serbia, 182 of them with a 
high average of over 9.00 who were taken as academic (potentially) donated because they are already academic achived. Independent variables were sex and success in studies, and dependent variable was intercultural sensitivity. The research used the method of nonexperimental systematic observation.

The basic finding separates the gifted students from the others and relates to the following: gifted students believe that the processes of mixing cultures can not and should not be stopped, because different ways of approximation in one way or the other way happen in time, especially today, when the world is networked and globalized. In this research, the gifts were defined for the positive side, the multicultural immigration flows in the EU, the multicultural communication of the individual, his determination in relation to the cultural traits of his and other peoples, that is, to accept plurality in intercultural exchanges of immigration in Europe today.

Findings are in favor of Kelly's view that gifted construct their own versions of reality themselves and act as if they are "real", by which each person constructs his own alternative constructions, opposing realism, i.e. the form of realism by which things are reduced to some of its aspects.

Acceptance of plurality, as a feature of the cognitive structures of gifted, is also related to the findings of the research as the basis for the interpretation of findings (Sternberg, Grigorenko and Zengov, according to Đurišić-Bojanović, 2009). Claiming that the holistic and integrative form of opinion is positive correlates with creative, abstract, complex, unusual ways of solving problems, while the analytical form of thinking is related to simpler, learned, concrete approaches.

The research of a complex integrative cognitive style leads in the direction that individuals with more pronounced dimensions of abstract thinking can better accept the plurality of ideas, and from the perspective of personal characteristics of a person with a complex integrative style, which would correspond to the gifts and could be taken as another step towards understanding the findings this research. The conclusion that obstacles to accepting plurality of ideas can be sought and in the personality traits opens a new chapter in this issue and suggests further, deeper consideration of these issues. 